\title{
Tobosa tiller defoliation patterns under rota- tional and continuous stocking
}

\author{
R.S. SENOCK, D.M. ANDERSON, L.W. MURRAY, AND G.B. DONART
}

\begin{abstract}
Authors are with the ET Laboratory, Dep. of Agronomy, Kansas State University, Manhattan 66506; Jornada Experimental Range, Agricultural Research, USDA, Box 30003, NMSU, Dep. 3JER, Las Cruces 88003-0003; Department of Experimental Statistics, New Mexico State University, Las Cruces 88003-0003; and Department of Animal and Range Sciences, New Mexico State University, Las Cruces 88003-0003, respectively.
\end{abstract}

\begin{abstract}
Continuous low animal density grazing of tobosa [Hilaria mutica (Buckl.) Benth.] in the northern Chihuahuan desert results in nonuniform forage utilization. Stocking smaller tobosa rangeland paddocks with high numbers of cattle for short periods of time may facilitate more uniform forage utilization. Two grazing periods in each of 2 consecutive years were monitored to investigate the frequency with which tobosa tillers were defoliated and the intensity of defoliation (change in height) in relation to grazing pressure under high-density seasonal rotational and low-density seasonal continuous grazing. Approximately $\mathbf{4 0} \%$ of tiller height, including leaves, was removed at each defoliation in the rotational treatment, while intensity of defoliation per grazing event remained consistent. In the continuous treatment, amount of tiller removed varied widely and was not consistent among the 4 periods. Percentage of tillers defoliated in the rotational treatment was always greater than $75 \%$, and always less than $30 \%$ in the continuous treatment. The probability that a tiller would be grazed at least once in the rotational treatment was more than twice as great as in the continuous treatment. However, within the rotational treatment, the probability of multiple grazing events $(\geq 2)$ on an individual tiller was less than the probability of a tiller being grazed just once. In general, high-density rotation grazing promoted more uniform forage utilization of tobosa than low-density continuous grazing.
\end{abstract}

Key Words: short duration grazing, grazing strategies, utilization, Grazing Pressure Index

Optimal sustained tiller utilization requires quantifying the intensity and frequency of defoliation in relation to the proportion of tillers grazed (Briske and Stuth 1982). Most previous studies have compared differences in stock densities or stocking rates

\footnotetext{
Cooperative investigations of the USDA Agriculture Research Service and the New Mexico Agricultural Experiment Station, Journal Article 1602, Agricultural Experiment Station, New Mexico State University, Las Cruces 88003 .

Manuscript accepted 30 Apr. 1993.
}

(Hodgson 1966, Greenwood and Arnold 1968, Hodgson and Ollerenshaw 1969, Morris 1969, Briske and Stuth 1982, Hinnant and Kothmann 1986, Hart and Balla 1982). The remaining studies have compared continuous and rotational grazing strategies (Gammon and Roberts 1978a, 1978b, 1978c; Pierson and Scarnecchia 1987), the influence of plant size on defoliation (Norton and Johnson 1981), and pasture usage (Hodgkinson 1980, Gillen et al. 1990). Most studies found frequency of defoliation to increase as stock density increased. There are less consistent results among studies in the defoliation intensity during an individual grazing event in relation to different grazing densities, pressures, or strategies. The lack of similar responses reported may be a function of pasture characteristics (Kothmann 1980) and emphasizes that the relationship between frequency and intensity of defoliation as a variable should be examined for different vegetation types.

Tobosa (Hilaria mutica [Buckl.] Benth.) is a highly productive, climax forage species on the adobe flood plains of the arid Southwest (Campbell 1931). Tobosa reproduces primarily by coarse rhizomes. Culms may attain $0.6 \mathrm{~m}$ in height. Tobosa grows in monotypic stands in southern New Mexico and is conventionally managed under continuous stocking during the growing season when culms are succulent and palatable. Culms become coarse and relatively unpalatable with increasing maturity (Paulsen and Ares 1962). Without periodic removal of old growth, such as through burning, tobosa culms and litter can accumulate and decrease future biomass production (Wright 1969). However, controlled burning does not always increase subsequent tobosa biomass (Dwyer 1972). Relatively high productivity coupled with slow decomposition rates under arid conditions (Weaver and Albertson 1956) promotes litter accumulation and reduces uniform utilization by livestock (Herbel and Nelson 1966, Anderson 1988). Shortduration rotational grazing, with smaller paddocks and increased grazing pressure, may improve forage utilization and limit biomass accumulation. Our objectives were to compare the frequency of 
defoliation and change in height (defoliation intensity) on individually marked tillers of tobosa under high-density seasonal rotational stocking and low-density seasonal continuous stocking.

\section{Materials and Methods}

Tobosa tiller defoliation patterns were evaluated during 1985 and 1986 under 2 stocking strategies. Paddocks were laid out in a dominant tobosa grass landscape containing small burrograss (Scleropogon brevifolius Phil.) aggregations that formed a mosaic plant community structure of monospecific grass stands (Devine 1987). The paddocks were located on the Jornada Experimental Range ( $\left.106^{\circ} 44^{\prime} \mathrm{W}, 32^{\circ} 29 \mathrm{~N}\right)$ in a playa basin containing fine, mixed, thermic Ustollic Haplargide soils (Stellar series) (Bulloch and Neher 1980) $37 \mathrm{~km}$ north of Las Cruces, New Mexico. Mean ambient air temperatures are highest in June $\left(36^{\circ} \mathrm{C}\right)$ and lowest in January $\left(13^{\circ} \mathrm{C}\right)$. Historical mean annual precipitation is $230 \mathrm{~mm}$, with $52 \%$ occurring within the July-September growing season (Paulsen and Ares 1962). A total of $255 \mathrm{~mm}$ of precipitation was received in 17 events which began 11 July and continued through 1 December 1985. Between 6 June and 7 December 1986, a total of $285 \mathrm{~mm}$ of precipitation was recorded among 24 events.

Previous stocking of treatments and paddock layout have been reported by Anderson $(1982,1988)$. The 2 stocking treatments used in this study consisted of a continuously stocked 33.6-ha paddock and a rotationally stocked, 34.7-ha, 1-herd, 11-paddock cell. The entire continuous paddock and one 2.9-ha area (paddock 7) in the 11-paddock rotational cell were used to compare grazing treatments. The rotational grazing pattern produced a variable length grazing period in paddock 7 (Table 1). Cell paddock 7 was grazed twice each year during the 2-year study. Yearling heifers were used in both treatments. The number of animals within each treatment was identical over years but differed between treatments based on previous data (Anderson 1988) that indicated the 34.7-ha cell (number of animals $=21$ ) to be inherently more productive than the 33.6-ha continuously stocked paddock (number of animals $=17$ ). Heifer liveweights ranged between 307 and $354 \mathrm{~kg}$ in 1985 and between 253 and $302 \mathrm{~kg}$ in 1986 . Overall seasonal stocking rates between treatments differed by $29.9 \mathrm{AUD} /$ ha in 1985 but only 6.4 AUD/ha in 1986 (Table 1).

Data were collected over 114 days in 1985. Initial monitoring began during active plant growth (August, 4 days), and a second period of monitoring was during dormancy (December, 8 days).
Because of different growing conditions in 1986, a total of 145 days of data were collected with both periods (July, 6 days; October, 6 days) occurring earlier during active plant growth compared to 1985.

In August 1985, 20 tobosa tillers were marked along each of 2 permanent transects in both treatments ( $n=40 /$ treatment). Transects were laid out at random distances from the water source in both treatments. In July 1986, the number of transects per treatment was doubled with a corresponding increase in the number of marked tillers to 80 per paddock. Even though more total precipitation was received during 1986 compared to 1985 between 2 and 23 August, only $10 \mathrm{~mm}$ of precipitation was received; therefore, most grass tillers senesced in both treatments. A 48-mm rainfall on 23 August 1986 initiated re-growth and the new tillers that were produced were marked and monitored for the second grazing period that ended in October.

Individual perimeter tillers were marked using colored plasticcovered wire loops. Tiller lengths were measured daily while animals were in cell paddock 7 . When cell paddock 7 was not stocked, only tillers in the continuous paddock were measured weekly. Tiller height was measured from the soil surface to the tip of the tallest vegetative structure. A leaf was classified as dead if it was senesced for more than half its length. The intensity of defoliation was defined as the amount of tiller height removed between measurements. Height removed was based on the previous day's measurements. Frequency of defoliation was defined as the number of times an individual tiller was grazed within a period, and was rated as having been nongrazed, grazed once, or grazed multiple times. Following a grazing event, tips of plant parts remaining were painted with white correction fluid. Subsequent removal of these white tips indicated re-grazing.

Mean above-ground biomass was estimated in both treatments by mowing plots $0.5 \mathrm{~m}$ wide and approximately $5.4 \mathrm{~m}$ in length to a 7.5-cm height with a gasoline-powered rotary lawn mower equipped with a grass-catcher. Two plots were mowed in each of the 11 paddocks in the cell and 20 plots in the continuous paddock. Except for the first period in 1986, plots in both treatments were mowed shortly before grazing began in cell paddock 7 . For the first monitoring period in July 1986, standing crop in both treatments was based on plots mowed during the previous dormant season. These standing crop estimates were considered representative of available biomass because biomass decomposition over the December-June period is probably minimal (Whitford et al. 1986). Active

Table 1. Time spent in paddocks (days), stocking rate (AUD/ha), mean standing crop (kg/ha) and Grazing Pressure Indices (AUD/kg) in tobosa paddocks managed under continuous and rotational stocking strategies between July and December in 1985 and 1986.

\begin{tabular}{|c|c|c|c|c|c|c|c|c|}
\hline & \multirow{3}{*}{$\begin{array}{c}\text { Time in } \\
\text { cell } \\
\text { pad. } 7\end{array}$} & \multicolumn{3}{|c|}{ Stocking rate } & \multirow{2}{*}{\multicolumn{2}{|c|}{$\begin{array}{c}\text { Initial mean above ground } \\
\text { biomass } \pm \text { Std. error }\end{array}$}} & \multirow{2}{*}{\multicolumn{2}{|c|}{$\begin{array}{l}\text { Initial Grazing } \\
\text { Pressure Index }\end{array}$}} \\
\hline & & \multicolumn{2}{|c|}{ Continuous paddock } & \multirow[b]{2}{*}{$\begin{array}{c}\text { Cell } \\
\text { pad. } 7\end{array}$} & & & & \\
\hline & & Season & $\begin{array}{l}\text { While } \\
\text { in pad } 7\end{array}$ & & $\begin{array}{l}\text { Cont. } \\
\text { pad. }\end{array}$ & $\begin{array}{c}\text { Cell } \\
\text { pad. } 7\end{array}$ & $\begin{array}{l}\text { Cont. } \\
\text { pad. }\end{array}$ & $\begin{array}{c}\text { Cell } \\
\text { pad. } 7\end{array}$ \\
\hline 1985 & (Days) & \multicolumn{3}{|c|}{$\ldots-($ AUD/ha) $\ldots \ldots$} & \multicolumn{2}{|c|}{$\ldots \ldots$} & \multicolumn{2}{|c|}{$\ldots$ (AUD/kg) $\cdots$} \\
\hline $\begin{array}{l}\text { Period } 1 \\
8-26 / 8-30\end{array}$ & 4 & 28.1 & 2.1 & 20.9 & $785 \pm 305$ & $438 \pm 84$ & .047 & .048 \\
\hline $\begin{array}{l}\text { Period 2 } \\
12-10 / 12-18\end{array}$ & 8 & 2.9 & 2.9 & 40.0 & $549 \pm 189$ & $353 \pm 98$ & .006 & .126 \\
\hline Overall & 12 & 31.0 & 5.0 & 60.9 & & & & \\
\hline $\begin{array}{l}1986 \\
\quad \text { Period } 1 \\
7-15 / 7-21\end{array}$ & 6 & 22.7 & 1.7 & 23.7 & $449 \pm 176$ & $353 \pm 98$ & .051 & .067 \\
\hline $\begin{array}{l}\text { Period 2 } \\
10-3 / 10-9\end{array}$ & 6 & 18.3 & 1.7 & 23.7 & $851 \pm 314$ & $675 \pm 342$ & .026 & .042 \\
\hline Overall & 12 & 41.0 & 3.4 & 47.4 & & & & \\
\hline
\end{tabular}


tobosa growth on the study site did not begin until after the first precipitation of the summer growing season that began in June. Grazing began less than 3 weeks after these rains. Grazing Pressure Indices were calculated for both treatments (Table 1) according to Scarnecchia and Kothmann (1982).

Treatments were not replicated; therefore, differences between treatments were determined by analysis of variance with a General Linear Models (GLM) procedure using subsamples (tillers within treatments) as the error term (SAS Institute 1985). Use of subsamples as an error term may result in an overly sensitive test but trends between treatments are valid.

Because monitoring periods between years differed in plant growth stage, defoliation intensity data, for grazed tillers only, were analyzed 2 different ways. First, for treatment differences within years, defoliation intensity was analyzed using treatment, period, and dates within periods as main effects. Secondly, treatment differences across years were compared for each period with treatment, year, and dates within year as main effects. In these analyses, the influence of tiller distance from the water source was evaluated as a covariate. Uniformity of grazing was examined by the distribution of tiller numbers within height categories at the end of the monitoring periods using chi-square analysis. For this analysis the monitoring periods in the continuous paddock corresponded to 2 periods totaling 114 days ( 106 and 8 days, respectively) in 1985 and the 2 periods in 1986 (81 and 65 days, respectively) that reflected 2 complete cycles through the cell. Frequency of defoliation data were analyzed by a categorical data modeling procedure (CATMOD, SAS Institute, 1985). Analyses were performed first within years with treatment and period as main effects and, secondly, between years within monitoring periods, using treatment and year as main effects. Percentages and standard errors were calculated for the main effects. Treatment comparisons for frequency of defoliation were restricted to equal lengths of time within periods, based on when the animals were in the rotational treatment. This was done to avoid the confounding effect of time on the marginal probabilities generated in the CATMOD procedure. Differences were considered significant if the probability of the Type I error was less than 0.05 .

\section{Results and Discussion}

\section{Grazing Pressure and Tiller Utilization}

Stocking density (number of head per ha) in cell paddock 7 was approximately 14 times greater than in the continuously stocked padd ock during both periods in 1985 and 1986 . In the continuously stocked paddock in 1985 stocking rate increased $0.8 \mathrm{AUD} /$ ha between period 1 and 2 compared to an increase of $19.1 \mathrm{AUD} / \mathrm{ha}$ in cell paddock 7 (Table 1). In 1986 cell paddock 7 was stocked for the same length of time in both periods. The Grazing Pressure Index values were approximately equal to or higher in cell paddock 7 than in the larger continuous paddock. For cell paddock 7 in 1985, the Grazing Pressure Index was higher in period 2 compared to period 1, while the reverse occurred in 1986 . The $48 \mathrm{~mm}$ of rainfall in late August 1986, which followed the nearly 8 weeks of drought, produced a new cohort of tillers and increased standing crop in both treatments before the second period of grazing. More standing crop ( 96 to $347 \mathrm{~kg} / \mathrm{ha}$ ) was mowed in the continuous paddock compared to cell paddock 7 over both periods in both years (Table 1). However, total mass of tobosa per unit area may be nutritionally misleading since gray tobosa contains only $4.7 \%$ crude protein and may comprise between 49 and $89 \%$ of the standing crop under continuous grazing (Anderson 1988).

More tillers were grazed in cell paddock 7 on a daily and seasonal basis than in the continuous paddock (Fig. 1). Overall, the percentage of tillers grazed at least once in the rotational paddock was greater than $75 \%$ in 1985 and $95 \%$ in 1986 . In contrast, the percentage of tillers grazed at least once in the continuous paddock over the whole season was never greater than $30 \%$ and there were several days in each grazing period when no defoliation was recorded.

Height reductions in the rotational paddock ranged from $27 \%$ to $66 \%$ in 1985 and $48 \%$ during both periods in 1986 (Table 2). When

Table 2. Daily mean ( \pm Standard errors) tiller height ${ }^{1}$ (mm) during 2 periods of cattle stocking in each of 2 years in a 2.9-ha cell paddock 7 and 33.6-ha continuously stocked paddock.

\begin{tabular}{|c|c|c|c|c|}
\hline \multirow[b]{2}{*}{ Date } & \multicolumn{2}{|c|}{ Tiller height before grazing } & \multicolumn{2}{|c|}{ Tiller height removed ${ }^{2}$} \\
\hline & $\begin{array}{l}\text { Continuously } \\
\text { stocked } \\
\text { paddock }\end{array}$ & $\begin{array}{c}\text { Cell } \\
\text { paddock } 7\end{array}$ & $\begin{array}{l}\text { Continuously } \\
\text { stocked } \\
\text { paddock }\end{array}$ & $\begin{array}{c}\text { Cell } \\
\text { paddock } 7\end{array}$ \\
\hline & \multicolumn{4}{|c|}{ August 1985} \\
\hline 27 & $234 \pm 10$ & $209 \pm 11$ & $18 \pm 2.3$ & $72 \pm 4.6$ \\
\hline 28 & $238 \pm 11$ & $200 \pm 12$ & $135 \pm 4.6$ & $85 \pm 11.0$ \\
\hline 29 & $240 \pm 11$ & $183 \pm 12$ & $135 \pm 3.5$ & $87 \pm 4.4$ \\
\hline 30 & $241 \pm 12$ & $164 \pm 13$ & & $66 \pm 4.5$ \\
\hline 31 & $245 \pm 12$ & $160 \pm 13$ & & $38 \pm 3.5$ \\
\hline \multicolumn{5}{|c|}{ December 1985} \\
\hline 11 & $236 \pm 28$ & $207 \pm 24$ & $33 \pm 6.9$ & $42 \pm 3.5$ \\
\hline 12 & $236 \pm 28$ & $192 \pm 25$ & $10 \pm 0.0$ & $102 \pm 12.7$ \\
\hline 13 & $236 \pm 28$ & $167 \pm 23$ & & $161 \pm 25.3$ \\
\hline 14 & $236 \pm 28$ & $157 \pm 22$ & & $193 \pm 79.9$ \\
\hline 15 & $236 \pm 25$ & $130 \pm 21$ & $140 \pm 0.0$ & $182 \pm 23.3$ \\
\hline 16 & $236 \pm 25$ & $109 \pm 18$ & & $140 \pm 29.0$ \\
\hline 17 & $236 \pm 25$ & $92 \pm 15$ & & $130 \pm 31.8$ \\
\hline 18 & $236 \pm 25$ & $71 \pm 4$ & & $175 \pm 43.8$ \\
\hline \multicolumn{5}{|l|}{ July 1986} \\
\hline 16 & $194 \pm 8$ & $218 \pm 5$ & $78 \pm 3.7$ & $84 \pm 2.5$ \\
\hline 17 & $194 \pm 8$ & $200 \pm 7$ & $42 \pm 2.1$ & $96 \pm 2.5$ \\
\hline 18 & $193 \pm 8$ & $179 \pm 7$ & $74 \pm 3.5$ & $66 \pm 2.2$ \\
\hline 19 & $191 \pm 8$ & $163 \pm 7$ & $140 \pm 31.8$ & $86 \pm 3.5$ \\
\hline 20 & $191 \pm 8$ & $151 \pm 7$ & $185 \pm 0.0$ & $68 \pm 2.8$ \\
\hline 21 & $191 \pm 8$ & $134 \pm 7$ & $10 \pm 0.0$ & $63 \pm 1.7$ \\
\hline \multicolumn{5}{|l|}{ October 1986} \\
\hline 3 & $165 \pm 5$ & $193 \pm 5$ & & $80 \pm 3.5$ \\
\hline 4 & $165 \pm 5$ & $173 \pm 6$ & $20 \pm 0.0$ & $85 \pm 2.1$ \\
\hline 5 & $164 \pm 5$ & $151 \pm 6$ & $37 \pm 13.4$ & $73 \pm 1.8$ \\
\hline 6 & $164 \pm 5$ & $123 \pm 5$ & $70 \pm 17.3$ & $103 \pm 2.2$ \\
\hline 7 & $162 \pm 5$ & $101 \pm 5$ & $70 \pm 5.8$ & $75 \pm 1.4$ \\
\hline
\end{tabular}

'Based on total marked tillers; $1985 \mathrm{n}=40$, $1986 \mathrm{n}=80$.

2Based on defoliated tillers.

comparing daily mean tiller height $(\mathrm{cm})$ across all 4 monitoring periods in the rotational paddock, a simple linear regression produced the equation of $\hat{Y}=222-1.7 * X\left(\mathrm{r}^{2}=0.87\right)$ where $\hat{Y}$ is tiller height and $X$ is day within grazing period. The slope of this equation indicates daily tiller height decreases of $1.7 \mathrm{~cm} \mathrm{day}^{-1} \mathrm{can}$ be expected when stocking with Grazing Pressure Indices between 0.04 and $0.13 \mathrm{AUD} / \mathrm{kg}$ (Table 1). In 1985 tiller height in the continuous paddock decreased only $17 \%$ from the maximum height attained $(287 \mathrm{~mm})$ during the year; in 1986, changes in height of individual tillers from grazing were offset by increases in height for the remaining nongrazed tillers because of plant growth.

The distributions of tiller heights at the end of grazing indicated uniform grazing in cell paddock 7 (Table 2). Differences between treatments were evident for all periods. After grazing, more than $85 \%$ of the tillers in the cell paddock 7 were $\leq 20 \mathrm{~cm}$ in height in all periods as compared to approximately $50 \%$ in the continuously stocked paddock. The distribution of tiller heights in the rotation paddock also differed between periods in 1985, while there were no differences between periods for either treatment in 1986.

\section{Intensity of Tiller Defoliation}

During the first period each year, intensity of defoliation in cell 

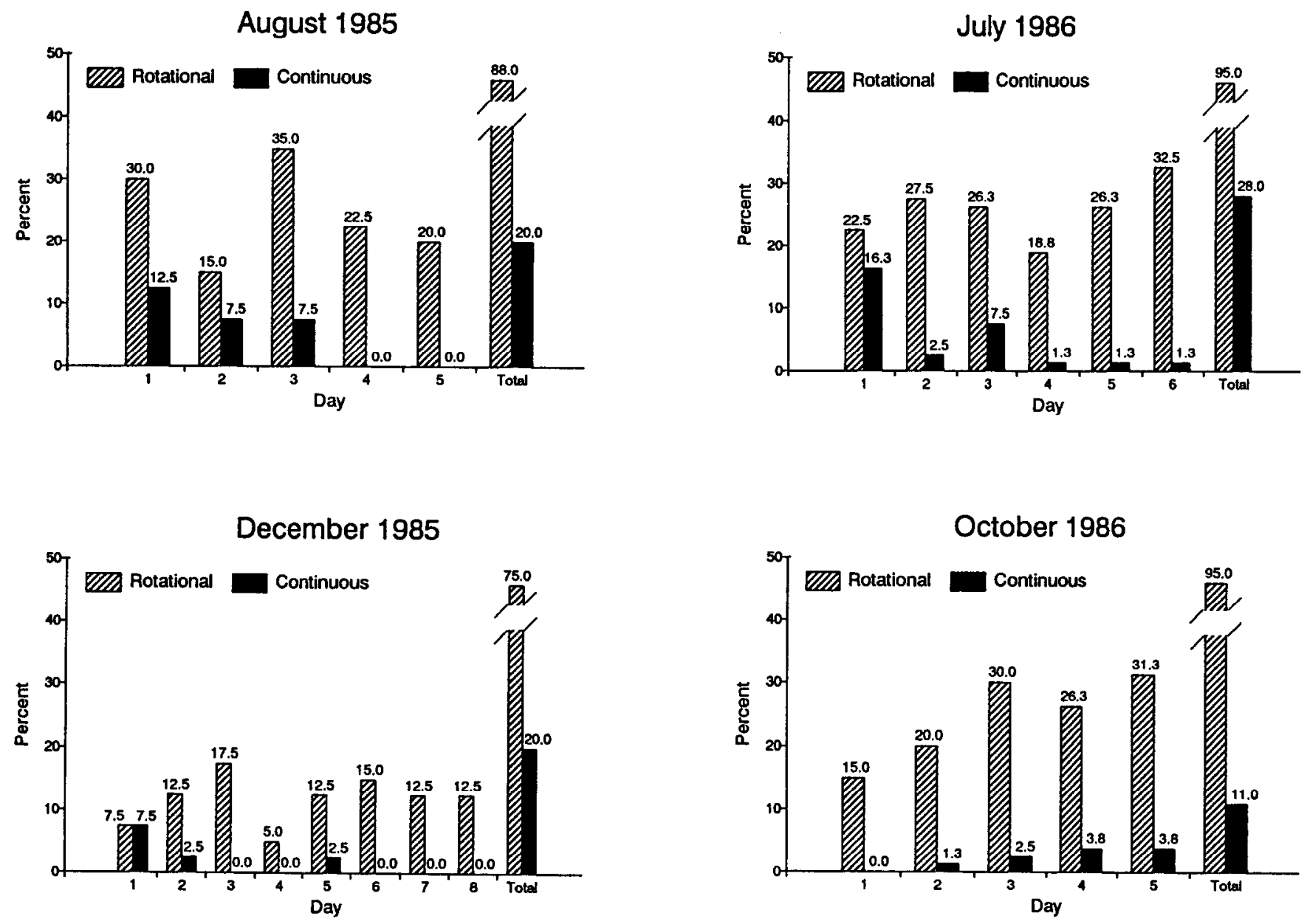

Fig. 1. Percentage of total marked tobosa tillers grazed daily in 1985 and 1986 during 4 separate monitoring periods under rotational and continuous stocking. For the rotational treatment the total bars are based on the final percentage of total marked tillers grazed during the monitoring period. For the continuous treatment in 1985 the totals are based on the entire season of grazing. In 1986 new tillers were marked in both treatments for the October monitoring period because all previously marked tillers died due to a mid-season drought.

paddock 7 removed only $36 \%$ of tiller height and was much more consistent than in the continuous paddock daily in height reductions (Table 2). The few grazing events recorded in the continuous paddock during all periods masked statistical differences between treatments within years. However, treatments did not differ between years, indicating consistency in treatment effects overtime. Defoliation intensity was also not influenced by distance from water. The short duration rotational grazing system resulted in a uniform low level of tiller utilization over the entire paddock.

Defoliation intensity was affected by period of grazing. During the second monitoring period in 1985 , defoliation intensity in cell paddock 7 was nearly double that of the first period. This is in contrast to Pierson and Scarnecchia (1987), who reported equal defoliation intensities in the early cycles of a rotational grazing treatment and a substantial decrease in intensity during the last cycle as plants matured. Although the forage had matured, some to the point of senescence, during the second period, forage availability may have also decreased to such levels that animals were forced to increase bite size to maintain forage intake. There were no differences in defoliation intensity between periods for either treatment in 1986 when standing crop increased from additional growth.

\section{Frequency of Tiller Defoliation}

Based on grazing events recorded for individual tillers in each period, there was a higher probability of grazing occurring in cell paddock 7 compared to the continuously stocked paddock (Table 4). Within cell paddock 7 , however, the probability of tillers being
Table 3. Percent of marked tillers within 4 height categories at the conclusion of grazing periods by year and treatment.

\begin{tabular}{llrrrr}
\hline \hline \multirow{2}{*}{$\begin{array}{l}\text { Final date of } \\
\text { grazing period }\end{array}$} & Treatment location & \multicolumn{5}{c}{ Height categories (cm) } \\
\cline { 3 - 6 } & & $0-10$ & $10-20$ & $20-30$ & $30-40$ \\
\hline & & & & & \\
1985 & & 25 & 60 & 8 & 7 \\
Aug. 30 & Cell paddock 7 & 83 & 17 & 0 & 0 \\
Dec. 18 & Cell paddock 7 & 8 & 38 & 29 & 25 \\
Dec. 18 & Continuous paddock & 8 & & & \\
1986 & & & & & \\
Jul. 21 & Cell paddock 7 & 53 & 39 & 7 & 1 \\
Sep. 22 & Continuous paddock & 6 & 44 & 33 & 17 \\
Oct. 9 & Cell paddock 7 & 58 & 38 & 4 & 0 \\
Nov. 26 & Continuous paddock & 3 & 55 & 16 & 26 \\
\hline
\end{tabular}

'Based on 40 and 80 tillers/treatment in 1985 and 1986, respectively.

re-grazed was much less than the probability of a single grazing. Tillers grazed more than once were grouped in a category termed multiple although the number of tillers grazed 3 or more times for either treatment in any grazing period was low $(\leq 3)$ and no trends were evident. Year and year by treatment interactions were not different, indicating consistent treatment effects. Within years, period by treatment interactions were also nonsignificant, indicating treatment differences in probabilities were maintained across periods. Thus the short duration grazing system resulted in only a single defoliation for the large majority of tillers in the rotational paddock, one of the objectives of short duration grazing using high 
Table 4. Mean marginal probabilitles ( \pm Standard errors) of graxing individual tillers by treatment and period of graxing in 1985 and $1986^{1}$.

\begin{tabular}{|c|c|c|c|c|}
\hline \multirow[b]{2}{*}{ Grazing events } & \multicolumn{2}{|c|}{ Treatment ${ }^{2}$} & \multicolumn{2}{|c|}{ Period $^{3}$} \\
\hline & Rotational & Continuous & First & Second \\
\hline & \multicolumn{4}{|c|}{1985} \\
\hline \multirow{4}{*}{$\begin{array}{l}\text { Non-grazed } \\
\text { Single } \\
\text { Multiple }^{4}\end{array}$} & $.30 \pm .050$ & $.84 \pm .042$ & $.46 \pm .055$ & $.67 \pm .052$ \\
\hline & $.46 \pm .055$ & $.16 \pm .041$ & $.34 \pm .052$ & $.29 \pm .050$ \\
\hline & $.24 \pm .047$ & $.00 \pm .010$ & $.20 \pm .044$ & $.04 \pm .024$ \\
\hline & \multicolumn{4}{|c|}{1986} \\
\hline Non-grazed & $.14 \pm .027$ & $.80 \pm .031$ & $.43 \pm .039$ & $.47 \pm .039$ \\
\hline Single & $.63 \pm .038$ & $.18 \pm .030$ & $.40 \pm .039$ & $.40 \pm .038$ \\
\hline Multiple4 & $.23 \pm .033$ & $.02 \pm .011$ & $.17 \pm .025$ & $.13 \pm .026$ \\
\hline
\end{tabular}

Treatment $\times$ period effects nonsignificant $(P>.05)$ in both years.

${ }^{2}$ Treatment effects significant $(P<.0001)$ in both years.

${ }^{3}$ Grazing period effects in $1985(P=0.05)$ and $1986(P=0.65)$.

4Multiple grazing events are $\geq 2$.

stock densities (Kothmann 1980). Gammon and Roberts (1978b) also reported most tillers received 2 or fewer defoliations per grazing period under rotational grazing. Other studies reported higher percentages of multiple defoliations under rotational heavy stocking (Pierson and Scarnecchia 1987). Thus vegetational characteristics of the pasture may affect frequency of defoliation.

The low number of multiple tiller defoliations seen in this study may have occurred due to the monotypic nature of the tobosa stands in the treatments. Monotypic vegetation may limit animal selectivity because few differences would exist among tillers to cause a particular tiller to receive greater defoliation as compared to another tiller. Studies involving whole plants in monotypic stands of the ceaspitose grass Agropyron cristatum (L.) Gaertn. have reported less than $20 \%$ of the grazed plants were defoliated more than once (Norton and Johnson 1981). Where multiple species with differing palatabilities are involved, frequency of defoliation may increase on the preferred species (Gammon and Roberts $1978 \mathrm{c}$, Briske and Stuth 1982, Gillen et al. 1990). The successful application of short duration grazing on tobosa pastures may be enhanced by the monotypic nature of the forage.

\section{Management Implications}

Flexibility in fixed continuous grazing strategies can basically be achieved only by adjustments in stocking rates (Vaughan-Evans 1978, as cited in Kothmann 1980). Stocking rates, however, are based on total forage demand by the animals over time and once set at the beginning of a grazing season typically undergo only minor adjustments over the course of a season. Continuous stocking limits flexibility since stocking rate adjustments cannot provide adequate control over defoliation frequency, especially on individual plants. Therefore, limited control of defoliation frequency can lead to deterioration of vegetation (Kothmann 1980). Rotational strategies provide the opportunity to improve harvest efficiency through better control and frequent adjustment of grazing pressure (Heitschmidt 1987). Smaller grazing land units can also be used to manipulate grazing pressure by changing livestock density without corresponding changes in stocking rate (Kothmann 1980). Results from this study provide an example on how to manipulate grazing pressures and control the frequency and intensity of tiller defoliation. The low probability of multiple grazings in cell paddock 7 for 2 periods within a year showed the majority of tillers received only a single defoliation.

The much lower grazing pressure in the continuous paddock resulted in a low probability of tiller grazing and especially regrazing during any period. Reduced tiller usage in the continuous paddock indicates large amounts of forage will remain ungrazed. Such material decays slowly (Weaver and Albertson 1956), and utilization by livestock decreases as plants mature and accumulate litter (Herbel and Nelson 1966) with the result that large areas of tobosa are simply avoided by livestock (Paulsen and Ares 1962). Uneven use was readily evident in the continuous paddock where large numbers of tillers were not grazed and substantial amounts of litter had accumulated. Minimal accumulation of standing dead and litter was observed in the 11-paddock cell.

The long-recommended use of tobosa growing on Chihuahuan desert range has been to graze during the summer growing season with deferment during fall-winter-spring (Paulsen and Ares 1962). Traditionally, tobosa rangeland has been managed under continuous conservative stocking during the summer in the arid Southwest (Anderson 1988). However, financial considerations frequently preclude implementation of specialized grazing strategies, especially if anticipated increases in livestock production are to pay for conventional fencing (Holechek 1992). Therefore a modified best pasture system (Martin and Ward 1970) offers an alternative to allow complete summer deferment of grazing on the more sensitive black grama-dropseed upland ranges if playa areas containing tobosa stands are available. This study indicates continuous stocking results in highly nonuniform usage of tobosa forage while high-density rotational stocking improves the total use of tobosa in a more uniform manner.

\section{Literature Cited}

Anderson, D.M. 1982. Seasonal stocking of semidesert tobosa rangeland in southern New Mexico, p. 137-142. In:D.D. Briske and M.M. Kothmann (eds.) Proc. Nat. Conf. on Grazing Manage. Tech., College Station, Tex. Anderson, D.M. 1988. Seasonal stocking of tobosa managed under continuous and rotational grazing. J. Range Manage. 41:78-83.

Briske, D.D., and J.W. Stuth. 1982. Tiller defoliation in a moderate and heavy grazing regime. J. Range Manage. 35:51 1-514.

Bulloch, H.E., Jr., and R.E. Neher. 1980. Soil survey of Dona Ana County area, New Mexico. USDA SCS.

Campbell, R.S. 1931. Plant succession and grazing capacity on clay soils in southern New Mexico. J. Agr. Res. 43:1027-1051.

Devine, D.L. 1987. A tobosa grass-burrograss mosaic community pattern in the northern Chihuahuan Desert. M.S. Thesis. New Mexico State Univ., Las Cruces.

Dwyer, D.D. 1972. Burning and nitrogen fertilization of tobosa grass. New Mexico Agr. Exp. Sta. Bull. 595.

Gammon, D.M., and B.R. Roberts. 1978a. Patterns of defoliation during continuous and rotational grazing of the Matopos Standveld of Rhodesia. 1. Selectivity of grazing. Rhod. J. Agr. Res. 16:117-131.

Gammon, D.M., and B.R. Roberts. 1978b. Patterns of defoliation during continuous and rotational grazing of the Matopos Standveld of Rhodesia. 2. Severity of defoliation. Rhod. J. Agr. Res. 16:133-145.

Gammon, D.M., and B.R. Roberts. 1978c. Patterns of defoliation during continuous and rotational grazing of the Matopos Standveld of Rhodesia. 3. Frequency of defoliation. Rhod. J. Agr. Res. 16:147-164.

Gillen, R.L., F.T. MeCollum, and J.E. Brummer. 1990. Tiller defoliation patterns under short duration grazing in tallgrass prairie. J. Range Manage. 43:95-99.

Greenwood, E.A.N., and G.W. Arnold. 1968. The quantity and frequency of removal of herbage from an emerging annual grass sward by sheep in a set-stocked system of grazing. J. Br. Grassl. Soc. 23:144-148.

Hart, R.H., and E.F. Balla. 1982. Forage production and removal from western and crested wheatgrass under grazing. J. Range Manage. 35:362-366.

Heitschmidt, R. 1987. Grazing systems and livestock management, p. 101-106. In: R.S. White and R.E. Short (eds.) Achieving efficient use of rangeland resources. Montana Agr. Exp. Sta., Bozeman, Feb. 1988.

Herbel, C.H., and A.B. Nelson. 1966. Species preference of Hereford and Santa Gertrudis cattle on a southern New Mexico range. J. Range Manage. 19:177-181.

Hinnant, R.T., and M.M. Kothmann. 1986. Monitoring intensity and uniformity of defoliation by tiller height measurements. 39th Annu. Meeting Soc. Range Manage. Kissimmee, Fla. Feb. 9-14, 1986. (Abstr.). Hodgkinson, K.C.1980. Frequency and extent of defoliation of herbaceous plants by sheep in a foothill range community in northern Utah. J. Range Manage. 33:164-169. 
Hodgson, J. 1966. The frequency of defoliation of individual tillers in a set-stocked sward. J. Br. Grassl. Soc. 21:258-263.

Hodgson, J., and J.H. Ollerenshaw. 1969. The frequency and severity of defoliation of individual tillers in set-stocked swards. J. Br. Grassl. Soc. 24:226-234.

Holechek, J.L. 1992. Financial benefits of range management practices in the Chihuahuan desert. Rangelands. 14:279-284.

Kothmann, M.M. 1980. Integrating livestock needs to the grazing system, p. 65-84. In: Proc. Grazing Manage. Systems for Southwest Rangelands Symp., K.C. McDaniel and C. Allison (eds.), New Mexico Agr. Ext. Serv. Las Cruces.

Martin, S.C., and D.E. Ward. 1970. Rotating access to water to improve semidesert cattle range near water. J. Range Manage. 23:22-26.

Morris, R.M. 1969. The pattern of grazing in continuously grazed swards. J. Br. Grassl. Soc. 24:65-70.

Norton, B.E., and P.S. Johnson. 1981. Patterns of defoliation by cattle grazing crested wheatgrass pastures, p. 462-464. In: Proc. XIV Int. Grassl. Congr., Lexington, Ky.

Paulsen, H.A., and F.N. Ares. 1962. Grazing values and management of black grama and tobosa grasslands and associated shrub ranges of the southwest. USDA Tech. Bull. 1270.
Pierson, F.B., and D.L. Scarnecchia. 1987. Defoliation of intermediate wheatgrass under seasonal and short-duration grazing. J. Range Manage. 40:228-232.

SAS Institute 1985. SAS $\otimes$ User’s guide: Statistics, Version 5 Edition, SAS Institute, Inc., Cary, N.C.

Scarnecchia, D.L., and M.M. Kothmann. 1982. A dynamic approach to grazing management terminology. J. Range Manage. 35:262-264.

Vaughan-Evans, R.H. 1978. Short-duration grazing improves veld conservation and farm income in the Que Group of I.C.A.'s. Conex Reportmimeo. Rhodesia.

Weaver, J.E., and F.W. Albertson. 1956. Grasslands of the Great Plains. Johnson Publ. Co., Nebr.

Whitford, W.G., Y. Steinberger, W. MacKay, L.W. Parker, D. Freckman, J.A. Wallwork, and D. Weems, 1986. Rainfall and decomposition in the Chihuahuan desert. Oecologia 68:512-515.

Wright, H.A. 1969. Effect of spring burning on tobosa grass. J. Range Manage. 22:425-427.

Moving?

Tell us your new address to keep your publications coming. SRM, 1839 York Street, Denver, Colorado 80206. 